CATALLAXY

Volume 3 Issue 1 June 2018

e-ISSN 2544-090X

¿ www.catallaxy.pl

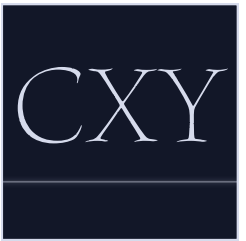

Oryginalny artykut naukowy

otrzymano: 06.05.2018 / zaakceptowano: 25.06.2018 / opublikowano online: 30.06 .2018

Pastor, K. (2018). Determinanty absorpcji środków z perspektywy finansowej 2007-2013 na poziomie powiatów. Catallaxy, 3(1): 27-39. doi:10.24136/cxy.2018.002.

\title{
Determinanty absorpcji środków z perspektywy finansowej 2007-2013 na poziomie powiatów
}

\author{
KAMIL PASTOR \\ Szkoła Gtówna Handlowa w Warszawie, al. Niepodlegtości 162, 02-554 Warszawa, Polska \\ వ pastorkamil@gmail.com \\ (iD) orcid.org/0000-0002-3239-0432
}

\begin{abstract}
Abstrakt
Motywacja: W latach 2007-2013 Polska była beneficjentem polityki spójności i uzyskała z budżetu unijnego ponad 67 mld EUR. Kryteria podziału funduszy były skomplikowane ze względu na mnogość grup docelowych oraz rozdrobnienie poszczególnych działań

Cel: Celem artykułu jest wyszczególnienie czynników, które najsilniej wpływały na absorpcję środków unijnych na poziomie powiatów. Postawiono dwa przypuszczenia: (1) absorpcja środków rośnie wraz z wyższym poziomem rozwoju powiatu (kanał konkurencyjności) oraz wraz z istotnie niższym poziomem rozwoju (kanał spójności); (2) kluczowe znaczenie dla poziomu absorpcji miała skuteczna polityka informacyjna oraz umiejętność wpasowania instrumentów polityki spójności w strategię rozwoju organizacji.

Materiały i metody: W artykule użyto ekonometrię przestrzenną. Wykorzystanie modeli przestrzennych umożliwito lepsze odwzorowanie zależności między powiatami.

Wyniki: Wykazano istotny statystycznie wpływ obu kanałów transmisji (konkurencyjności i spójności). Wyniki modelu sugerują, że większe znaczenie dla poziomu wykorzystania środków miały czynniki związane z konkurencyjnością regionów.
\end{abstract}

Stowa kluczowe: polityka spójności; fundusze unijne; ekonometria przestrzenna JEL: C31; E61; F02; H54; O11

\section{Wprowadzenie}

W ramach polityki spójności, w perspektywie finansowej 2007-2013, Polska uzyskała łącznie ponad 67 mld EUR $z$ budżetu unijnego (MRR, 2007, s. 115). Rokrocznie podmioty krajowe uzyskiwały środki $\mathrm{w}$ wysokości ok. 1,5-2,0\% PKB (po uwzględnieniu wsparcia $z$ budżetu krajowego). Finansowana $z$ nich była znaczna część inwestycji. Polityka spójności szczególnie ważną rolę miała w przy- padku inwestycji samorządów, które aż w $41 \%$ przeprowadzone zostały $z$ wykorzystaniem tych środków (Imapp, 2017, s. 7).

Celem artykułu jest wyszczególnienie czynników oraz siły potencjalnej zależności między dostępnymi danymi ilościowymi obrazującymi sytuację społeczno-gospodarczą w powiatach a uzyskanym dofinansowaniem per capita. Punktem wyjścia pozostaje oficjalna strategia programu. Cele polityki spójności, zapisane w Narodowych Strategicznych Ramach 
Odniesienia (NSRO), dotyczyły przede wszystkim: (1) zmniejszenia stopnia dysproporcji w rozwoju gospodarczym i społecznym oraz (2) zwiększenia poziomu konkurencyjności i innowacyjności polskiej gospodarki (MRR, 2007, s. 42). O ile pierwszy z celów dotyczył całego społeczeństwa, a jego grupą docelową były podmioty mające trudności w odnalezieniu się we współczesnej gospodarce („wsparcie słabiej rozwiniętych"), to drugi $z$ nich miał charakter wspierania innowacyjnych sektorów gospodarki („wsparcie najbardziej rozwiniętych"). Wzrost wydajności i konkurencyjności prowadzi do koncentracji działalności gospodarczej, natomiast dążenie do zniwelowania różnic między regionami, poprzez wyrównanie, ogranicza tę koncentracje (Gorzelak, 2008, ss. 78-80). Widoczna jest tu swego rodzaju strategiczna sprzeczność między spójnością („równością”) a konkurencyjnością („efektywnością”).

Można więc przypuszczać, że absorpcja środków wzrastała wraz $z$ wyższym poziomem rozwoju powiatu (bardziej rozwinięte przedsiębiorstwa zdobywały wyższe dofinansowania większej liczby projektów), jak i niższym poziomem rozwoju (polityka spójności ma na celu pomoc słabiej rozwiniętym regionom).

Drugim przypuszczeniem, które można postawić jest pozytywna zależność między zmienną ukrytą „jakość instytucji regionalnych" a wysokością uzyskanych funduszy. $\mathrm{W}$ tych regionach, w których istniała długoterminowa strategia rozwoju, występowała kadra urzędnicza potrafiąca wykorzystać możliwości oferowane przez środki unijne oraz zmniejszać koszty aplikacji (nie tylko finansowe) dla lokalnych przedsiębiorstw, absorpcja środków powinna być wyższa.

W sekcji 2. przedstawiono przegląd literatury dotyczącej przestrzennego aspektu absorpcji środków unijnych. W sekcji 3. opisano narzędzia ekonometrii przestrzennej, wykorzystane dane oraz strukturę stworzonego modelu. W sekcji 4. przedstawiono wyniki estymacji i ich interpretację. W sekcji 5 . zawarto dyskusję nad wynikami oraz analizę zróżnicowania siły determinant $\mathrm{w}$ podgrupie zamożnych i biednych powiatów. Sekcja 6. stanowi podsumowanie uzyskanych wniosków.

\section{Przegląd literatury}

W ramach badań ewaluacyjnych przeprowadzono wiele analiz dotyczących NSRO w zakresie skuteczności, efektywności czy wpływu poszczególnych instrumentów i działań. Najczęstszymi narzędziami ewaluacyjnymi pozostawały metody jakościowe, badania ankietowe, modelowanie DSGE (Dynamic Stochastic General Equilibrium Model) (np. za pomocą modeli klasy HERMIN, QUEST, EUImpact czy WISE VESPA) (Bukowski i in., 2007, ss. 22-26; Ciężka i in., 2017; Zaleski, 2010), czy wprowadzone dopiero niedawno analizy kontrfaktyczne (Agrotec i in., 2016). Badania dotyczące czynników wpływających na wykorzystanie środków unijnych najczęściej dotyczyły poszczególnego instrumentu, działania czy grupy docelowej i oparte były na badaniach ankietowych. Słuzyły one przede wszystkim celom ewaluacyjnym. Prowadzone były badania na temat determinant skuteczności czy nawet samego faktu aplikowania o środki wśród podmiotów (Hryniewicka, 2015, ss. 303-312). Wynika $z$ nich, że wśród małych i średnich przedsiębiorstw, najwyższą skutecznością aplikowania cechowały się najefektywniejsze podmioty w poszczególnych branżach (osiągające zysk, dokonujące inwestycji). Niezbyt liczne są natomiast analizy, które próbują uzasadnić determinanty absorpcji środków w ujęciu makroekonomicznym i regionalnym. Częściowo wynika to faktu, że grupy docelowe i kryteria ustalane były bezpośrednio przez instytucje zarządzające. Trudno jednak jest dokonać agregacji kryteriów 420 różniących się od siebie działań przeznaczonych dla zupełnie innych instytucji (od kół gospodyń wiejskich przez przedsiębiorstwa do uczelni wyższych) oraz obejmujących różne obszary państwa (wpływ programów regionalnych). 


\section{Materiały i metody}

\subsection{Opis użytych danych}

Dane użyte $w$ niniejszej analizie pochodzą z zasobów Ministerstwa Inwestycji i Rozwoju (MiiR, 2018), z Banku Danych Lokalnych (BDL, 2018) oraz z portalu Mojapolis (2017). Wysokość środków oraz ich przyporządkowanie do poszczególnych powiatów ustalono na podstawie raportu pochodzącego z Krajowego Systemu Informatycznego (KSI SIMIK, 2018), zawierającego informacje o wszystkich, zrealizowanych projektach oraz powiatach oddziaływania. Łączna wartość dofinansowania, przeznaczona na wszystkie projekty wyniosła 319 mld PLN. Ze względu na to, że w trakcie składania wniosków o uzyskanie dofinansowania nie wymagano informacji o regionie, w którym dany projekt będzie realizowany oraz generalnie niską jakość statystyk, dane te należy traktować jako przybliżone. Wykluczono projekty dotyczące obsługi technicznej polityki spójności (obsługa administracyjna dystrybuowania, jak i rozliczania środków unijnych) oraz projekty transportowe i energetyczne. Pominięcie dwóch ostatnich rodzajów projektów (tematy priorytetów 16-43) wynikało $z$ ich istotnego wpływu na wyniki podczas, gdy były to często pojedyncze inwestycje na wielką skalę (np. budowa terminala LNG (liquefied natural gas) w Świnoujściu czy dofinansowanie budowy elektrowni wiatrowych w powiecie kołobrzeskim na $92 \mathrm{mln}$ PLN). Z uwagi na ogromną wartość tych projektów (ok. $132 \mathrm{mld}$ PLN), jak i centralne planowanie tras autostrad, magistral kolejowych czy elektrowni, ich uwzględnienie zakłócałoby potencjalnie istniejące zależności. Wśród pozostałych projektów, które uzyskały dofinansowanie o wartości 187 mld PLN, dane o powiecie oddziaływania występowały tylko dla 144 mld PLN. Dokładniejsze dane, wraz $z$ podziałem na programy operacyjne, zawarto w tabeli 1., natomiast strukturę przestrzenną podziału na rysunku 1 .

W przypadku pozostałych danych na temat sytuacji ekonomiczno-społecznej powiatów uwzględniono, o ile było to możliwe, średnią danego wskaźnika $z$ lat 2007-2015. Okres ten wybrano $z$ uwagi na fakt, że konkursy ogłaszane były przez cały czas trwania perspektywy (lata 2007-2013), jak i zasadę „n+2” (termin rozliczenia projektów mija dwa lata po zakończeniu perspektywy). Decyzja o wyborze zakresu czasowego nie powinna mieć znacznego wpływu na wyniki, gdyż efekty zrealizowanych projektów na użyte $\mathrm{w}$ modelu zmienne, powinny pozostawać relatywnie niewielkie (poza wskaźnikiem bezrobocia i zadłużenia). Wynika to przede wszystkim z nieznacznej wysokości wsparcia $w$ odniesieniu do PKB.

W tabeli 2. przedstawiono szczegółowe informacje na temat użytych zmiennych. Wszystkie zmienne wystandaryzowano w celu umożliwienia oceny siły występujących zależności.

\subsection{Użyte metody ekonometryczne}

Powiązania przestrzenne mogą być modelowane za pomocą ekonometrii przestrzennej. Podstawową kwestią, często sprawiającą wiele problemów, jest wybór sposobu powiązań między poszczególnymi jednostkami. W przypadku niniejszego badania, zdecydowano się na najpopularniejszą macierz wag przestrzennych - macierz sąsiedztwa. Istnieją silne przesłanki by zakładać, że powiaty graniczące ze sobą powinny mieć więcej cech wspólnych niż powiaty odległe - chociażby ze względu na podobne rynki pracy, jakość instytucji czy podobny poziom zamożności. Konkurencyjna macierz zakładająca istnienie powiązania mię$\mathrm{dzy}$ regionami znajdującymi się $\mathrm{w}$ odległości mniejszej niż $50 \mathrm{~km}$, okazała się być gorsza (na podstawie globalnego testu Morana).

Można wyróżnić trzy podstawowe modele oddziaływania przestrzennego:

- autoregresja przestrzenna (spatial autoregression, SAR), dana wzorem (1):

$\mathbf{y}=\rho \mathbf{W} \mathbf{y}+\mathbf{X} \boldsymbol{\beta}+\varepsilon$,

- autoregresja przestrzenna błędów (spatial error model, SEM), dana wzorem (2): 


$$
\begin{aligned}
& \mathbf{y}=\mathbf{X} \boldsymbol{\beta}+\varepsilon, \\
& \varepsilon=\lambda \mathbf{W} \boldsymbol{\epsilon}+\boldsymbol{\mu} ;
\end{aligned}
$$

- przestrzenne efekty zarażania (spatial lag of X, SLX, spatial spillovers), dane wzorem (3):

$\mathbf{y}=\mathbf{X} \boldsymbol{\beta}+\mathbf{W} \mathbf{X} \theta+\varepsilon$,

gdzie:

$y$ - zmienna objaśniana,

$\rho \quad-\quad$ współczynnik autoregresji przestrzennej,

W - macierz wag przestrzennych,

$\mathbf{X}$ - macierz zmiennych objaśniających,

$\boldsymbol{\beta}$ - wektor oszacowań parametrów $\mathbf{X}$,

$\varepsilon$ - wektor reszt,

$\lambda$ - współczynnik autoregresji składnika losowego,

$\epsilon$ - wektor reszt w modelu SEM,

$\boldsymbol{\mu}$ - składnik losowy w procesie autokorelacji błędu,

$\theta$ - współczynnik oszacowań parametrów $\mathbf{X}$ w sąsiednich jednostkach.

Możliwe jest uwzględnienie $w$ modelu więcej niż jednego źródła procesu przestrzennego. Zakładając obecność autoregresji przestrzennej (SAR) oraz autoregresji przestrzennej błędów (SEM), otrzymuje się model SARAR, w przypadku SAR i SLX - spatial Durbin model (SDM), a SEM i SLX - spatial Durbin error model (SDEM). Istnieje również model general nesting (GNS), zakładający obecność wszystkich trzech procesów (Elhorst i Vega, 2015). Ze względu na niską identyfikowalność nie jest on jednak zbyt często używany w praktyce.

Procedura wyboru właściwego modelu niestety nie jest jednoznaczna. Popularne są dwie metody: „od ogółu do szczegółu” — od modelu GNS do KMNK oraz „od szczegółu do ogółu" - od KMNK do GNS. W procedurze wyboru uwzględniono następujące kwestie:

- istotność statystyczna parametrów $\rho, \lambda$ i $\theta$;

- wartość kryteriów Akaike (AIC) modeli;

- wyniki testów LM między dwoma rozpatrywanymi modelami;

- zgodność z intuicją ekonomiczną oraz brak kanibalizacji zmiennych.
Jednoznaczna identyfikacja właściwego źródła procesu lub procesów przestrzennych jest przeważnie bardzo trudna (Cook $\mathrm{i}$ in., 2015, s. 28). Dokładne rozgraniczenie wpływu poszczególnych procesów jest $\mathrm{w}$ praktyce niemożliwe. Dodatkowo, wybór metody ma wpływ na to, jaki model zostanie uznany za właściwy. Występuje analogia do modeli klasy AR (autoregressive model) i MA (moving average model), które w przypadku odwracalności i stacjonarności, mogą być przedstawione za pomocą drugiego $z$ modeli. Teoria ekonometrii nie daje więc odpowiedzi na pytanie jaki model wybrać. Z badań wykorzystujących metody Monte Carlo wynika, że modele SARAR i SDEM pozwalają na osiągnięcie nieobciążonej estymacji $\boldsymbol{\beta}$ oraz dają największe szanse na uniknięcie wniosków pozornych odnośnie parametrów przestrzennych (Cook i in., 2015). Wskazówek może dostarczać również teoria i wyobrażenie ekonometryka na temat kanałów transmisji danego zjawiska.

\subsection{Model determinant absorpcji}

Początkowo, zgodnie z podejściem „od szczegółu do ogółu" stworzono model MNK tłumaczący wysokość dofinansowania per capita $\mathrm{w}$ danym powiecie szeregiem zmiennych społeczno-ekonomicznych. Mimo istotnych statystycznie zmiennych (zarówno łącznie $z$ wykorzystaniem testu Walda, jak i indywidualnie), model ten nie przeszedl pozytywnie testu RESET (regression specification error test), charakteryzował się nienormalnym rozkładem reszt oraz heteroskedastycznością. Modelu tego nie można było więc uznać za właściwy. Dlatego też wskazana była jego modyfikacja.

Czynnikami wpływającymi negatywnie na wyniki były nieuwzględniona wcześniej zmienna ukryta i występowanie procesów przestrzennych. W celu poprawienia jakości, modelu posłużono się ekonometrią przestrzenną. Za macierz wag przestrzennych przyjęto macierz sąsiedztwa W. Przez to pojęcie rozumie się, że jednostką powiązaną powiatu są wszystkie powiaty, z którymi dany powiat graniczy. Wykorzystując ma- 
cierz $\mathbf{W}$ przeprowadzono testy weryfikujące występowanie procesów przestrzennych. Wynik globalnego testu Morana sugerowal, że zarówno $w$ resztach $z$ modelu szacowanego KMNK (p-value równe 0,024), jak i w samych danych o dofinansowaniu per capita ( $p$-value równe $1,8 \cdot 10^{-8}$ ), występował pewien, nieznany jeszcze, proces przestrzenny.

W toku procedury doboru odpowiedniej struktury modelu (za pomocą metod „od szczegółu do ogółu” oraz „od ogółu do szczegółu”), przestrzenny model Durbina z błędem (SDEM) okazał się być najlepszypod względem kryterium AIC, jak i istotności parametrów opisujących dany typ procesu przestrzennego. Minimalnie lepszy, pod względem kryterium AIC, był model SDM, jednak niższa istotność parametru $\rho$ skłania do wyboru modelu SDEM. Model SARAR odrzucono ze względu na kanibalizację efektów przestrzennych. Porównanie modeli przedstawiono $\mathrm{w}$ tabeli 3 . Dodatkowych informacji dostarczył test LM, w przypadku którego hipoteza zerowa zakłada brak występowania procesu przestrzennego, a hipoteza alternatywna konkretne ich źródło/źródła. Najniższe prawdopodobieństwo testowe ( $p$-value) wystąpiło w teście, w którym alternatywą było występowanie właśnie procesu przestrzennego składnika losowego oraz przestrzenne efekty zarażania (test RLMlag). Te właśnie procesy występowały $\mathrm{w}$ modelu SDEM.

Można więc wywnioskować, że na poziom dofinansowania per capita $\mathrm{w}$ danym powiecie wpływa również sytuacja społeczno-ekonomiczna w powiatach sąsiednich. Bliskość bardziej rozwiniętego pod tym względem powiatu, powinna więc pozytywnie wpływać na poziom absorpcji. Dodatkowo, występuje proces przestrzenny reszt, którego zadaniem jest uwzględnienie ich przestrzennego skupiania. Taka sytuacja może zachodzić $\mathrm{w}$ przypadku, gdy $\mathrm{w}$ danym regionie i $\mathrm{w}$ jego sąsiedztwie, występuje czynnik nieobserwowalny, który wpływa na poziom zmiennej objaśnianej. Potencjalnym wytłumaczeniem może być również jakość danych. Drugim, bardziej technicznym celem uwzględnienia procesu przestrzennego reszt, było zmniej- szenie heteroskedastyczności i autokorelacji składnika losowego - czyli występowania regionów, w których poziom absorpcji systematycznie różnił się od tego, który wynikał $z$ modelu. Uwzględnienie procesów przestrzennych, mimo pewnej poprawy, nie wyeliminowało całkowicie $z$ modelu heteroskedastyczności, na co wskazywał wynik testu Breuscha-Pagana.

W przypadku modeli przestrzennych nie można interpretować bezpośrednio wyników estymacji modelu - należy obliczyć efekty całkowite uwzględniające fakt, że na wynik $\mathrm{w}$ danym powiecie oddziałują również powiaty sąsiednie.

\section{Wyniki badania}

Analizując wyniki estymacji (tabela 4.) można wyróżnić dwie grupy czynników. Pierwszą $z$ nich są czynniki związane $z$ wysokim poziomem rozwoju powiatu. Dość intuicyjne wydaje się, że im więcej podmiotów w powiecie, tym więcej środków podmioty te są $\mathrm{w}$ stanie otrzymać. Zgodnie z wynikami modelu, wyższa liczba podmiotów $\mathrm{w}$ powiatach sąsiednich obniżała poziom absorpcji. Istotnym czynnikiem wpływającym na poziom absorpcji środków była też liczba organizacji pozarządowych na 1000 mieszkańców w powiecie. Organizacje te zazwyczaj aktywnie poszukują zewnętrznych źródeł finansowania, jak i są swego rodzaju wyznacznikiem poziomu rozwoju społecznego (wysokiego kapitału społecznego). Wpływ udziału organizacji pozarządowych w całkowitej liczbie podmiotów, jak i liczby podmiotów na 1000 mieszkańców, stawał się nieistotny po uwzględnieniu przestrzennego oddziaływania tego efektu wpływ bezpośredni w większości się znosił.

Dodatnio, na absorpcję per capita, wpływał wyższy odsetek podmiotów z sektora kreatywnego $\mathrm{w}$ nowopowstałych podmiotach. Była to jedna $z$ ważniejszych determinant absorpcji (wzrost tej zmiennej w powiecie o jedno odchylenie standardowe powodowal wzrost poziomu absorpcji przeciętnie o 0,55 odchylenia). Klasa kreatywna, utożsamiana $z$ najbardziej twórczymi mieszkańcami dużych miast, 
zdaniem amerykańskiego ekonomisty i socjologa R. Floridy (2003, ss. 8, 69), jest motorem napędowym miast postindustrialnych. Do sektora kreatywnego zaliczają się podmioty zajmujące się działalnością artystyczno-technologiczną (np. branże: reklamowa, modowa, medialna, ale też tworzenie oprogramowania i gier komputerowych czy design). Za pomocą tej zmiennej, możliwe jest rozróżnienie powiatów pod względem poziomu rozwoju. Trzeba jednak przyznać, że jej istotność może częściowo wynikać z kryteriów aplikacyjnych. Możliwość uzyskania środków zewnętrznych zachęcała mieszkańców do zakładania przedsiębiorstw klasyfikowanych jako kreatywne, aby móc te środki uzyskać, np. Działanie PO IG 8.1 skierowane do start-upów technologicznych, spowodowało masowe zakładanie przedsiębiorstw głównie w celu uzyskania dotacji (Rauzer i in., 2015, s. 66). Widoczna była też zależność między wyższymi nakładami na inwestycje a uzyskanymi przez podmioty $z$ powiatu środkami. W regionach, w których już ponoszono wyższe nakłady inwestycyjne, przedsiębiorstwa i samorządy uzyskały wyższe dofinansowanie ze środków polityki spójności. W niewielkiej części może to również być wynik samej interwencji - dotacje przeznaczane były w przeważającej części na inwestycje. Interesująca jest również zależność między liczbą ludności w powiecie a dofinansowaniem per capita - potwierdza to przypuszczenie, że powiaty miejskie (zazwyczaj o większej liczbie ludności), charakteryzują się wyższym dofinansowaniem, zarówno w ujęciu per capita, jak i bezwzględnym. Wyższa gęstość zaludnienia sprzyja więc wykorzystaniu środków unijnych.

Drugą grupą czynników są te, związane $z$ wyrównywaniem szans i wsparciem gorzej rozwiniętych regionów. Widoczny jest pozytywny wpływ stopy bezrobocia na stopień absorpcji funduszy. Przyczyna jest dość oczywista - jednym $z$ celów polityki spójności było wsparcie tych regionów, które były najbardziej zapóźnione gospodarczo, a wysoka stopa bezrobocia oznacza, że w danym regionie występują szczególne trudności gospodarcze. Można również zauważyć, że bezrobocie miało silniejszy, całkowity efekt bezwzględny niż średnie wynagrodzenie.

Wyższe wsparcie dla regionów biedniejszych potwierdza również obserwacja, że w powiatach należących do Polski Wschodniej (objętej dodatkowo dedykowanym tylko jej Programem Operacyjnym Rozwój Polski Wschodniej, PO RPW), zaobserwowano wyższy poziom dofinansowania przeciętnie o 0,6 odchylenia standardowego.

Na poziom absorpcji środków negatywnie wpływała wysokość wydatków jednostek samorządowych per capita. Ujemny wpływ salda budżetowego powiatów na mieszkańca można interpretować dwojako. Z jednej strony, w powiatach o wyższym deficycie, mniej prawdopodobne jest zrealizowanie inwestycji, gdyż wymagany jest udział środków własnych, które trudniej jest wygospodarować, gdy występuje deficyt. Z drugiej strony, wysokie, ujemne saldo budżetu może oznaczać, że powiat zadłużał się, aby realizować inwestycje współfinansowane $z$ funduszy unijnych. Wydaje się jednak, że ten pierwszy efekt jest silniejszy. Wpływ samego poziomu zadłużenia powiatów okazal się być nieistotny, dlatego nie uwzględniono go w modelu. Wytypowane i opisane zmienne wybrano na podstawie bayesowskiego uśredniania modeli na podstawie zbioru danych dostępnych w BDL (2018) i Mojapolis (2018).

\section{Dyskusja na temat wyników}

Po podzieleniu powiatów na dwie równoliczne grupy według poziomu zamożności (poziom zamożności według indeksu LHDI_zamoznosc), można zauważyć, że opisywane zależności nie były stabilne $\mathrm{w}$ obu podpróbach ${ }^{1}$. $\mathrm{W}$ powiatach zamożniejszych były one silniejsze, a w powiatach biedniejszych o wiele słabsze (najsilniejszy pozostawał wpływ bezrobocia i udziału w PO RPW). Podmioty w powiatach bogatszych miały łatwiejszy i dogodniejszy dostęp, zarówno do informacji o możliwości skorzystania $z$ funduszy unijnych, jak i pośredników, którzy będą w stanie wesprzeć przedsiębiorstwo czy stowarzysze-

Wnioski na podstawie aprzestrzennego modelu KMNK. 
nie w ubieganiu się o środki. Aspekty związane $z$ niedostateczną promocją czy słabym poziomem komunikacji między instytucjami zarządzającymi programami a potencjalnymi beneficjentami, były często podnoszone w ewaluacjach i raportach (Ledzion, 2015, ss. 7-8). Oznacza to, że podmioty, które lepiej potrafily odnaleźć instrumenty wpisujące się w swoją strategię rozwoju, były w stanie uzyskać wyższe dofinansowanie. Wbrew pozorom, wybór optymalnego rodzaju wsparcia był skomplikowany. Występowało wiele kanibalizujących się instrumentów uruchamianych $\mathrm{w}$ różnych okresach, ze skomplikowaną (zazwyczaj) procedurą ubiegania się o środki. Uzyskanie "darmowych" środków wymagało często znacznego nakładu pracy, co w przypadku wielu małych przedsiębiorstw, było istotnym czynnikiem ograniczającym. Stąd też podmioty, dla których koszt (nie tylko finansowy) aplikowania o środki był wyższy, miały mniejszą motywację, aby o nie się ubiegać. Z wcześniej wspomnianych badań (Hryniewicka, 2015, ss. 303-312), wynika, że wyższe prawdopodobieństwo zdobycia środków unijnych miały przedsiębiorstwa, które generalnie były liderami w swoich branżach lub przynajmniej dobrze prosperowały. W powiatach gorzej rozwiniętych, takich przedsiębiorstw było zazwyczaj mniej.

Stąd też może wynikać niski stopień zależności uzyskanego dofinansowania per capita w powiatach biedniejszych. W takich powiatach o wiele częściej brakuje kadr, które byłyby w stanie skutecznie aplikować o dofinansowania. Tam, gdzie podmioty były w stanie pokonać wyżej opisane trudności, osiągany poziom dofinansowania był wyższy. Duże znaczenie miała też sprawna komunikacja między instytucje pośredniczącymi a potencjalnymi beneficjentami oraz istnienie przedsiębiorstw wspomagających potencjalnych beneficjentów $\mathrm{w}$ procesie aplikacji.

\section{Zakończenie}

Na podstawie uzyskanych wyników można potwierdzić przypuszczenie o pozytywnym wpływie czynników świadczących o wysokim, jak i niskim poziomie rozwoju powiatów na wysokość dofinansowania. $Z$ dwóch celów NSRO (spójność i konkurencyjność), silniejszy wpływ wydaje się mieć ten drugi. Dodatkowo, występują pewne przesłanki pozwalające sądzić, że drugie przypuszczenie zakładające istnienie zmiennej ukrytej dotyczącej jakości promocji i wsparcia programów unijnych, również można uznać za potwierdzone. Interpretując siłę poszczególnych czynników warto wspomnieć, że bezrobocie w każdym z modeli miało o wiele wyższą istotność, przykładowo od poziomu wynagrodzenia. Najistotniejszą zmienną $\mathrm{w}$ modelu pozostawał udział podmiotów kreatywnych w ogóle nowozakładanych podmiotów. Na podstawie wyników można więc wyciągnąć wniosek, że na NSRO w latach 2007-2013 skorzystały nie tylko najsłabiej rozwinięte powiaty, ale przede wszystkim te, które już wówczas charakteryzowały się wysokim poziomem zamożności oraz obecnością nowoczesnych gałęzi przemysłu i usług.

\section{Bibliografia}

Agrotec., WYG PSDB., \& EGO. (2016). Ewaluacja wplywu Programu Operacyjnego Rozwój Polski Wschodniej 2007-2013 (PO RPW) na rozwój przedsiębiorczości w Polsce Wschodniej. Pobrane 01.05.2018 z https://www.ewaluacja.gov.pl.

BDL. (2018). Pobrane 01.05.2018 z https://bdl.stat. gov.pl.

Bukowski, M., Dyrda, S., Marć, Ł., i Skrok, Ł. (2007). Reakcja gospodarki polskiej na fundusze strukturalne w latach 2007-2013 - wnioski dla Polski. Pobrane 01.05.2018 z http://ibs.org.pl.

Ciężka, B., Gąska, J., Mazurowska, O., Pastor, K., Siedlecka, U., i Widła-Domaradzki, Ł. (2017). Wplyw Polityki Spójności 2007-2013 na konkurencyjność przedsiębiorstw i rozwój przedsiębiorczości w Polsce. Pobrane 01.05.2018 z https:// www.ewaluacja.gov.pl.

Cook, S.J., Hays, J.C., i Franzese, R.J. (2015). Model specification and spatial interdependence. Pobrane 01.05.2018 z http://www.sas.rochester.edu.

Elhorst, J.P, \& Vega, H.S. (2017). The SLX model: Extensions and the sensitivity of spatial spillovers to W. Papeles de Economia Espanola, 152. 
Florida, R.L. (2003). The rise of the creative class: and how it's transforming work, leisure, community and everyday life. New York: Hazard Press.

Gorzelak, G. (2008). Fakty i mity rozwoju regionalnego. Zarzadzanie Publiczne, 4(6).

Hryniewicka, M., (2015). Wpływ funduszy unijnych na rozwój sektora MŚP w Polsce w latach 2007-2013. Warszawa: Difin.

Imapp. (2017). Efekty polityki spójności 2007-2013 $w$ Polsce, krajach Grupy Wyszehradzkiej i państwach partnerskich. Pobrane 01.05.2018 z https://www.ewaluacja.gov.pl.

KSI SIMIK. (2018). Pobrane 01.05.2018 z https:// www.funduszeeuropejskie.2007-2013.gov.pl.

Ledzion, B. (red.). (2015). Ewaluacja strategiczna działań informacyjno-promocyjnych realizowa$n y c h w$ ramach PO KL. Pobrane 01.05.2018 z https://www.ewaluacja.gov.pl.

MIiR. (2018). Pobrane 01.05.2018 z https://www. funduszeeuropejskie.2007-2013.gov.pl.

Mojapolis. (2017). Pobrane 27.12.2017 z http:// www.mojapolis.pl.
MRR. (2007). Narodowe Strategiczne Ramy Odniesienia 2007-2013 wspierajace wzrost gospodarczy i zatrudnienie. Narodowa Strategia Spójności. Pobrane 01.05.2018 z https://www.funduszeeuropejskie.2007-2013.gov.pl.

Rauzer, A., Gołoś, A., i Pander, W. (2015). Barometr innowacyjności. Raport końcowy z ewaluacji on-going działań Programu Operacyjnego Innowacyjna Gospodarka na lata 2007-2013, skierowanych do przedsiębiorstw. Pobrane 01.05.2018 $z$ http://badania.parp.gov.pl.

Zaleski, J. (2010). Raport końcowy. Oszacowanie wartości wskaźników odzwierciedlajacych cele Regionalnego Programu Operacyjnego Województwa Mazowieckiego 2007-2013 przy użyciu modelu makroekonomicznego HERMIN. Pobrane 01.05.2018 z http://www.rpo.mazowia.eu.

Informacje uzupetniające

Wkład autorski: autor zaakceptował ostateczną wersję artykułu.

Źródła finansowania: artykuł został w całości sfinansowany ze środków własnych autora. 
Aneks

Tabela 1.

Struktura dofinansowania w podziale na programy operacyjne i tematy priorytetów ( $w$ mln PLN)

\begin{tabular}{|c|c|c|c|c|}
\hline Nazwa programu operacyjnego & $\begin{array}{c}\text { Eączne } \\
\text { dofinansowanie }\end{array}$ & $\begin{array}{c}\text { Transport, } \\
\text { energetyka, pomoc } \\
\text { techniczna }\end{array}$ & $\begin{array}{l}\text { Pozostałe tematy } \\
\text { priorytetów }\end{array}$ & $\begin{array}{c}\text { Pozostałe tematy - } \\
\text { dostępne dane } \\
\text { o powiecie }\end{array}$ \\
\hline PO Infrastruktura i Środowisko & 134852 & 93752 & 41100 & 37022 \\
\hline PO Innowacyjna Gospodarka & 44111 & 903 & 43208 & 31863 \\
\hline PO Kapitał Ludzki & 50424 & 3438 & 46987 & 24914 \\
\hline PO Pomoc techniczna & 2333 & 2333 & 0 & 0 \\
\hline PO Rozwój Polski Wschodniej & 11039 & 5077 & 5961 & 4388 \\
\hline RPO Województwa Dolnośląskiego & 5370 & 1330 & 4040 & 4040 \\
\hline $\begin{array}{l}\text { RPO Województwa Kujawsko- } \\
\text { Pomorskiego }\end{array}$ & 4399 & 1479 & 2920 & 2920 \\
\hline RPO Województwa Lubelskiego & 5280 & 1815 & 3464 & 3453 \\
\hline RPO Województwa Lubuskiego & 2172 & 802 & 1370 & 1301 \\
\hline RPO Województwa Đódzkiego & 4654 & 1548 & 3106 & 2871 \\
\hline RPO Województwa Małopolskiego & 6236 & 2207 & 4029 & 3878 \\
\hline RPO Województwa Mazowieckiego & 8271 & 3061 & 5209 & 5209 \\
\hline RPO Województwa Opolskiego & 2177 & 737 & 1440 & 1440 \\
\hline RPO Województwa Podkarpackiego & 5372 & 1988 & 3384 & 3256 \\
\hline RPO Województwa Podlaskiego & 3193 & 1358 & 1835 & 1588 \\
\hline RPO Województwa Pomorskiego & 4097 & 1497 & 2600 & 2005 \\
\hline RPO Województwa Śląskiego & 7645 & 2240 & 5405 & 5013 \\
\hline RPO Województwa Świętokrzyskiego & 3273 & 1074 & 2198 & 2080 \\
\hline $\begin{array}{l}\text { RPO Województwa Warmińsko- } \\
\text { Mazurskiego }\end{array}$ & 4682 & 1868 & 2814 & 2654 \\
\hline $\begin{array}{l}\text { RPO Województwa Wielkopolskiego } \\
\text { na lata 2007-2013 }\end{array}$ & 5945 & 2160 & 3784 & 2682 \\
\hline $\begin{array}{l}\text { RPO Województwa } \\
\text { Zachodniopomorskiego }\end{array}$ & 3866 & 1467 & 2399 & 1875 \\
\hline suma & 319389 & 132135 & 187253 & 144453 \\
\hline
\end{tabular}

Uwagi:

$\mathrm{PO}$ - Program Operacyjny;

$\mathrm{RPO}$ - Regionalny Program Operacyjny.

Źródło: Opracowanie własne na podstawie danych KSI SIMIK (2018). 
Tabela 2 .

Lista zmiennych zastosowanych w modelu

\begin{tabular}{|c|c|c|c|}
\hline Nazwa zmiennej & Jednostka & Oznaczenie & Źródło \\
\hline $\begin{array}{l}\text { wysokość otrzymanego dofinansowania w ramach polityki } \\
\text { spójności na mieszkańca }\end{array}$ & PLN & dofin_per_capita & $\begin{array}{l}\text { KSI SIMIK (2018), } \\
\text { BDL (2018) }\end{array}$ \\
\hline $\begin{array}{l}\text { liczba podmiotów wpisanych do rejestru REGON na } 1000 \\
\text { mieszkańców }\end{array}$ & liczba & podmioty_na_1000 & BDL (2018) \\
\hline $\begin{array}{l}\text { liczba fundacji, stowarzyszeń i organizacji społecznych na } 100 \\
\text { mieszkańców }\end{array}$ & liczba & NGO_na_1000 & BDL (2018) \\
\hline $\begin{array}{l}\text { udział nowo zarejestrowanych podmiotów sektora kreatywnego } \\
\text { w liczbie nowo zarejestrowanych podmiotów ogółem }\end{array}$ & $\%$ & sektor_kreatywny & BDL (2018) \\
\hline saldo budżetu powiatu na mieszkańca & PLN & saldo_per_capita & BDL (2018) \\
\hline stopa bezrobocia w powiecie & $\%$ & bezrobocie & BDL (2018) \\
\hline przeciętne wynagrodzenie w powiecie & PLN & wynagrodzenia & BDL (2018) \\
\hline przynależność do województw objętych programem PO RPW & $\begin{array}{l}\text { zmienna } \\
\text { binarna }\end{array}$ & polska_wschodnia & - \\
\hline wydatki powiatów na mieszkańca & PLN & wydatki_per_capita & BDL (2018) \\
\hline $\begin{array}{l}\text { nakłady inwestycyjne przedsiębiorstw na mieszkańca (średnia } \\
2008-2015 \text { ) }\end{array}$ & PLN & naktady_inw & BDL (2018) \\
\hline liczba mieszkańców w powiecie & liczba & ludnose & BDL (2018) \\
\hline $\begin{array}{l}\text { Lokalny Wskaźnik Rozwoju Społecznego (Local Human Deve- } \\
\text { lopment Index, LHDI) (wymiar zamożności) }\end{array}$ & $\begin{array}{l}\text { wskaźnik } \\
0-100\end{array}$ & LHDI_zamoznosc & Mojapolis (2017) \\
\hline
\end{tabular}

Uwagi:

Jeżeli nie podano inaczej w analizie użyto średnią wartość wskaźnika w latach 2007-2015.

Źródło: Opracowanie własne.

Tabela 3.

Porównanie wyników estymacji modeli

\begin{tabular}{lccc}
\hline \multicolumn{1}{c}{ Nazwa modelu } & Kryterium AIC & Istotność parametrów przestrzennych & Statystyka testu LM \\
\hline model liniowy MNK & 884,9 & - & - \\
model SLM & 877,5 & $\rho=0,22$ & LMlag=8,01 \\
model SEM & 883,4 & $\lambda=0,16$ & LMerr $=2,78$ \\
model SLX & 864,0 & $\rho=0,37, \lambda=-0,22$ & - \\
model SARAR & 877,3 & $\rho=0,13$ & RLerr $=3,94$ \\
model SDM & 863,1 & $\lambda=0,17$ & RLMlag=9,18 \\
model SDEM & 863,2 & $\rho=-0,15, \lambda=0,30$ & - \\
model GNS & 863,5 & &
\end{tabular}

Źródło: Opracowanie własne. 
Tabela 4.

Efekty bezpośrednie, pośrednie i całkowite modelu SDEM

\begin{tabular}{lccc}
\hline \multicolumn{1}{c}{ Nazwa zmiennej } & Efekt bezpośredni & Efekt pośredni & Efekt całkowity \\
\hline podmioty_na_1000 & $0,25^{* * *}$ & $-0,17$ & 0,08 \\
NGO_na_1000 & $0,28^{* * *}$ & $-0,13$ & 0,15 \\
sektor_kreatywny & $0,14^{* *}$ & $0,40^{* * *}$ & $0,55^{* * *}$ \\
saldo_per_capita & $-0,25^{* * *}$ & $-0,26$ & $-0,5^{* *}$ \\
bezrobocie & $0,17^{* * *}$ & $0,18^{*}$ & $0,34^{* * *}$ \\
wynagrodzenia & $0,12^{* *}$ & $-0,11$ & $-0,23^{*}$ \\
polska_wschodnia & - & - & $0,62^{* * *}$ \\
wydatki_per_capita & $-0,22^{* * *}$ & $-0,11$ & $-0,34^{*}$ \\
naktady_inw & $0,23^{* * *}$ & 0,18 & $0,41^{* * *}$ \\
ludnosc & $0,14^{* * *}$ & $0,24^{* *}$ & $0,38^{* * *}$ \\
\hline
\end{tabular}

\section{Uwagi:}

Zmienna polska_wschodnia nie posiada opóźnienia przestrzennego, znaczenie ma to, czy dany powiat a nie jego sąsiad znajduje się w obszarze objętym PO RPW.

******* oznacza istotność statystyczną odpowiednio poniżej 0,1, 0,05 i 0,01.

Źródło: Opracowanie własne. 
Rysunek 1 .

Struktura dofinansowania w ujęciu przestrzennym w podziale na kwantyle (w PLN)

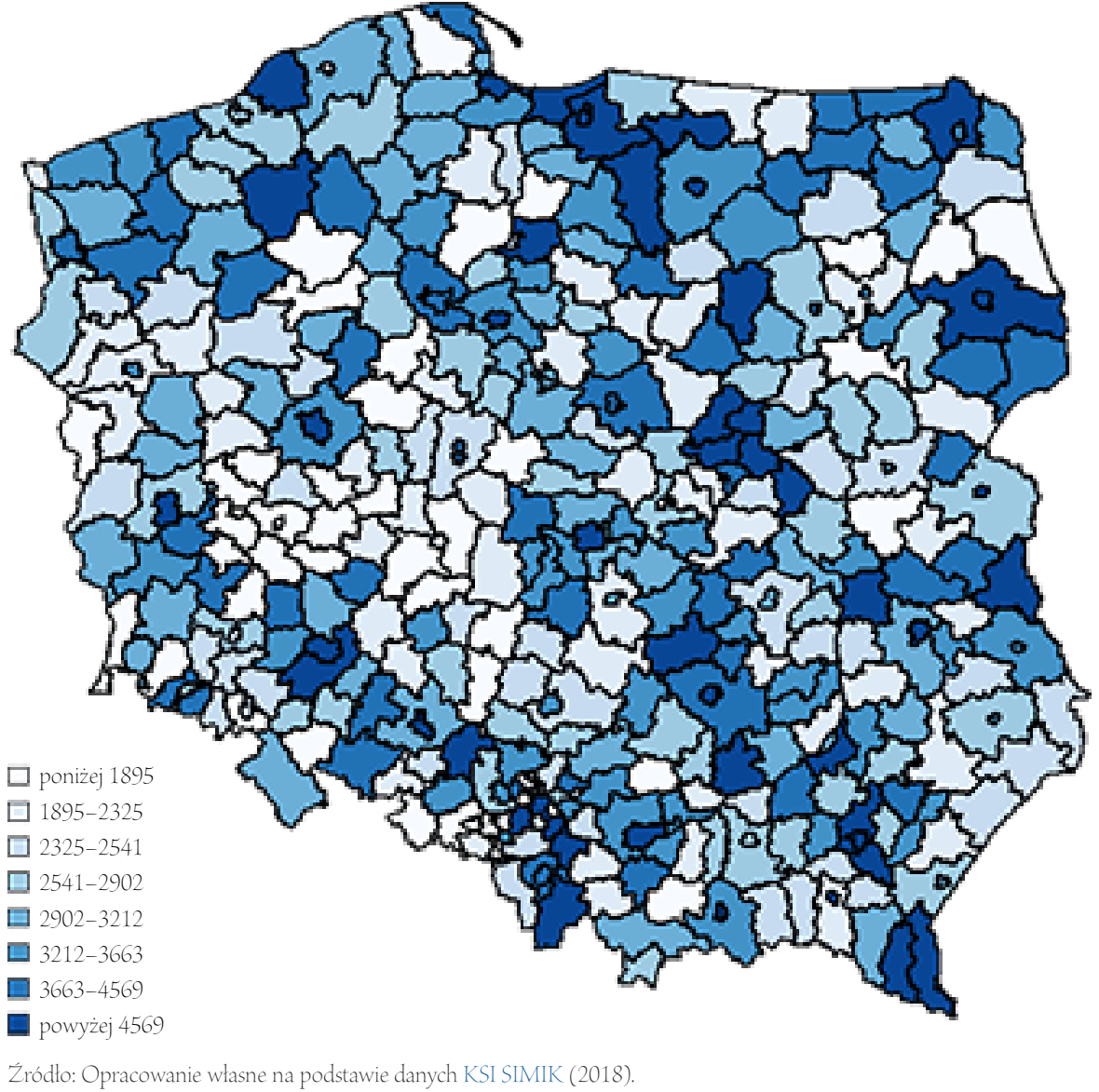


Determinants of funds absorption from the financial perspective 2007-2013 on the districts level

\section{Abstract}

Motivation: Poland benefited from cohesion funds in 2007-2013 and gained more than 67 bln EUR from the European budget. The criteria of the distribution of these funds were multifaceted, because of the occurrence of many different target groups and fragmentation of instruments.

Aim: The main aim of the article was to determine factors, which had the strongest impact on the absorption of European funds on district level in Poland. Two assumptions were made: (1) absorption level rises along with a higher level of district development (competitiveness channel) and with significantly lower level of development (cohesion channel); (2) the proper information policy as well as the ability to fit European funds support into organisation strategy played a key role for the level of absorption.

Materials and methods: Spatial econometrics was used in the article. The usage of spatial relations facilitated the creation of a better fitted model.

Results: The statistically significant impact of both channels (competitiveness and cohesion channels) was noted. The results from the model suggest that the competitiveness of the regions had more impact on absorption than a low level of development.

Keywords: cohesion policy; European funds; spatial econometrics JEL: C31; E61; F02; H54; O11 
